\title{
Learning Barriers: Challenges and Concerns
}

\section{Zainab Ibrahim Ciroma}

\author{
The Federal Polytechnic Damaturu
} P.M.B 1006, Damaturu, Yobe State

\section{Doi:10.5901/ ajis.2014.v3n7p142}

\section{Abstract}

Learning is a process that involves the teacher, parent and the learner - but learning cannot be achieved where there are hindrance; some independents to learning in our educational system can be attributed to learners, challenges and concerns of both the teacher and learner, these learners hinder the learning process and in most cases stigmata the importing of reliable knowledge and skills, the learners include each of qualified teachers, use of language, too many student in a class, lack of supervision by head of schools and motivation of learners, the challenges cover ways to enhance learning at schools home and the contribution of the government to the process. The concerns at highlight the status of our educational system showing where we are leading to, which necessitates the need to find a lasting school to the learning banners if learning is to be effective in our educational system now and in the next generation.

\section{Introduction}

Learning is a term that both the teacher and student are familiar with especially in the education domain, learning has been defined by many scholars and a cursory look at them will shed light on how learning is achieved.

Oladele, (1989) says Mukleyee (1978) defined learning as the influence from some performance of an organism manifesting a change of behavior.

Tolman; (1959) also see learning as dependent upon what he callcognitive maps which are built out of experiences a a change in the way of person acts in a particular situation. From the aforementioned definition on learning, it can be concluded that change in behavior is achieved in the child or adult and involves a process. This study will look at learning barriers, its challenges and concerns in the education domain.

\section{Learning Barriers}

Learning barriers occur when a person's ability to learn is jeopardized. This can be environmental issues; learning disabilities mental health has taken a new dimension in which other learning barriers have emerged that needs to be examined. Learning is categorically a change in behaviour of the learner through instruction and experience, learning can be hindered when barriers are evident as of teacher, I have come across this issues of learning barriers which include language, too many students in a class, lack of supervision by heads of schools, lack of library, qualified teachers and motivating students to learn more by giving rewards.

\section{Language}

It is said that language marks the world of man it is what distinguishes man from animal, It is the first form of communication between mother and child closely followed by the environment the child lives in. in the aspect of learning, language is the only mediumthat can convey knowledge. In societies where the official language is not the widely spoken married problem arisesin the learning process. A typical example is in Yobe state where majority of the peoples speak their indigenous languages they are exposed to English in primary school; most parents there don't value pre-primary school in which case the child does not hear the English language until later. It becomes evident in later years the inability of the child to grasp what is been taught and the performance becomes very poor, though some children are exceptionally bright they learn the language in the shortest possible time. 


\section{Too Many Students in a Class}

In a situation where there are too students in a class, learning is also hindered. A class should consist of maximum thirty students where the teacher can control and attend to the learning need of the students. Learning materials can also easily go round and the teacher can test the students with ease. A class of hundred students is difficult to control and the possibility of many students not learning is greater in percentage.

\section{Lack of Supervision by Heads of Schools}

In recent times most schools don't supervise their teachers or their lesson notes. Some teachers on theother hand play truancy. They teach a subject haphazardly without paying attention to whether the students have understoodthe topicor not. The job of the head of school is to go round the school premises to see how the students are being taught. He/ she should read the lesson plan on time so that the teacher goes to class with his/her lesson plan. The head can also ask the students questions on what is being taught to see how much they havelearnt. This will check any problems of learning.

\section{Lack of Functional Library}

Anotherimportant aspect to learning barriers is lack of qualified teachers trained in specific subjects and method of teaching. Most teachers don't take time to study and get more information on the topic to be taught. In the age of internet, research is made easy at the same time the teacher can use local examples to highlight his/her point during explanation in class. The issue of teachers going for further studies is good but not entirely relevant. There is need to improve on what is on ground in training the teacher to be more versatile in discharging his/her responsibility of teaching before going for further studies. Nowadays there are so many professors, doctors, masters holders but the quality of students have not improved in recent times. Why may we ask? Institutions and government are paying attention to the degrees of teachers not their input or quality of graduates they are producing. Most of the time some graduates can't defend their certificates and the relevant bodies turns a blind eye ignoring these threat in our educational domain.

\section{Motivation of the Learner}

Motivation is referred to as the activation or arousal of behaviour giving it strength and direction. It is also the energy that prompts people to act motivation helps the learner to be proactive and perform credibly well. The teacher should give gifts or endearments to the learner in which others would strive to receive the same gifts and in this case the whole class would become very competitive. Words of encourage also play a part in motivating the learner.

The barriers of learning as propounded by scholars are many but this paper seeks to the learners and teachers experience coupled with needs of the learners to become learned. The points highlighted above look at learning barriers, the next issue is challenges of learning and how to overcome the barriers.

\section{Challenges}

There are so many challenges to the learner faces; it could be inadequate learning materials, conducive atmosphere to learn, teacher role and most importantly lack of new initiative and support from relevant bodies or institution.

\section{Inadequate Learning Materials}

This constitutes one of the greatest challenges to the learner. For example, I teach literature in my school and surprisingly the students have to be conjured to buy novels, play and poetry books. Imagine going to class to teach Macbeth and the students don't have the play at hand, what happens. They look at you without really understanding what the whole story is about, at the end of the day their performance in the exam is very poor. This type of situation exists all over the country and it is said that nothing is done about it. The learner can only achieve his/her goal by the study of books.

\section{Creating a Conductive Environment for Learning}

In Nigeria today, the learning environment is a thing of concern to the teacher and student. Leaking roof stops, lack of 
enough tables and chairs, no cross ventilation sometimes the chalk to write with a problem. These hinder learning by creating distractions in form of heat, rain or some student not sitting down. It annoys the teacher who on his part needs total concentration of the leaner, imparting knowledge in this circumstance is challenging.

\section{Rules of Teachers}

The teacher is the foundation of the school and on whom the great task of imparting knowledge lies with, the need of having hard working and determined teachers cannot be overemphasized. Teachers should handle their students with care and patience. Theymust show sincerity of purpose and tackle every problem with the required expertise. They should not be teachers for teaching sake but must love to teach and not mind so much on the take home cheque though teacher need to survive. The ultimate joy is to see that you have changed an individual who will become great one day. The role of the teacher is paramount in the education domain because he/she is also a second parent, adviser, friend etc. they need total dedication to their job and all the encouragement and motivation for a better output in the learners.

The challenge the learner faces is surmountable with the right policies checks and balances these problems can be totally eradicated. The relevant bodies involved should find a lasting solution to the challenges the learner faces so as to have a learning free environment beneficial to the end users.

\section{Concerns}

It would not be of place to ask where education is heading to, is the society better for it? How can we improve the standard of education in Nigeria? These questions need to be answered because when we talk of the learner it is invariably looking at the education system. Nigeria has had her ups and down recently and one can safely say that education has lost its real value for upliftment, change in behaviour and development. These goals can only be achieved when you study or go to school. Every year universities produce graduates that have gone through the university without achieving a set of goal. Obtaining the certificate is one thing, defending it is another. While majority of the graduates are half baked, the number of professors are on the increate, and note still the students are not really learned. Where lays the problems. It is a language problem too many students in a class, lack of motivation etc. the teacher can take preventive measures and ease the task of the studentin learning educationist can also provide an avenue in which indigenous languages can be used to teach. For example countries like China, Russia, and Malaysia etc. all teach in their languages and you find out that their output is far ahead of Nigeria

Thechallenges faced by the learners can be taken care of. The environment a student learns is equally important as the teacher who imparts knowledge. The school and parents must contribute in uplifting the standard of education in their domain because the government makes policies and don't really test the viability of these policies which in most cases is not advantageous to the learner. They should take in to cognizance the people and their natural affiliation in making education policies.

On a final note, it would be wise if Nigeria as a country drafts new policies of her own without copying the British or American system of education taking into consideration the many ethnic and religious groups by gettinginformation on how bestto improve and tackle any problems associated with learning. In this way the issue of learning barriers can be eradicated in the future to set the stage for a new generation of learned intellectuals

\section{References}

AsabeMamman (2005) Introduction in Educational Foundation. Jimeta - YolaAMS publication

BollesR. C.(1976) Learning Theorist 2nd Edition New York, Holt and Winston

Bloom B. S. (1976) Human Characteristics and short learning New-York McGraw Hill Company.

Clover, S.A. and Brunning, R.H. (1990) Educational Psychology Principles

Hull C.L. (1943) Principles of behaviours. New -York Appleton.

Mohammed LabaranDawa (2009) Theories of learning and Implication for Counseling, Zaria: Mutallib Enterprises.

M.L. Dawa S.R. Jebson et-al (2009) Learning Theories the Counselors Perspective Zaria, Mutallib Enterprises

Mukheryee, A (1978) Educational Physiology for teacher, Students and parentsCalaitta K.P Basic Publishers co.

Naomi N. Adamu (2009) Problems of Learning and Motivation Implication For counseling in learning theories the counselors Perspective (2009)Zaria, Mutallib Enterprises.

Oladele, J. O. (1998) Fundamental of Psychological foundation of Education

Okoli G.E.(ed) (2002) Reading in Psychology of learning a simplified Approach. Lagos Gods Glory Publishing Co.

Parlor, I.P. (1927) Conditioned reflexes Tress by G.V Brep, London Oxford University Press. 
Folman E.C. (1959) Principle of purposive Behaviour in Kicks, (ed) Psychology: A study of a Science Vol.2 New York McGrew - Hill. Tolman, E.C. (1932) Purposive behaviour in Animal and Man. New York Century Press. Thorndike E. L. (1932) Fundamental of Learning, New- York Teachers College Press. 